\title{
MENINGKATKAN KEMAMPUAN KOMUNIKASI MATEMATIK SISWA MA MELALUI CONTEXTUAL TEACHING AND LEARNING
}

\author{
Siti Ruqoyyah \\ Sitiruqoyyah13@gmail.com \\ Program Studi PGSD, Fakultas Ilmu Pendidikan, IKIP Siliwangi
}

\begin{abstract}
ABSTRAK
Penelitian ini dilatarbelakangi oleh rendahnya kemampuan komunikasi matematik siswa MA. Oleh karena itu, diperlukan suatu pendekatan untuk meningkatkan kemampuan komunikasi matematik siswa MA. Tujuan dalam penelitian adalah untuk menelaah pencapaian dan peningkatan kemampuan komunikasi matematik siswa yang memperoleh pembelajaran dengan Contextual Teaching and Learning dengan siswa yang memperoleh pembelajaran biasa. Penelitian ini berjenis kuasi eksperimen dengan desain pretes posttest control group design. Populasi dalam penelitian ini adalah seluruh siswa di salah satu MA di Kota Cimahi, sedangkan sampel ditentukan dengan menggunakan teknik purposive sampling diperoleh sampel yaitu X MIA sebagai kelas eksperimen sebanyak 20 siswa dan kelas $\mathrm{X}$ IIS sebagai kelas kontrol sebanyak 20 siswa. Instrumen yang digunakan terdiri dari tes kemampuan komunikasi. Hasil penelitian menunjukkan bahwa pencapaian dan peningkatan kemampuan komunikasi matematik siswa MA yang pembelajarannya menggunakan Contextual Teaching and Learning lebih baik daripada yang menggunakan pembelajaran biasa.
\end{abstract}

Kata Kunci: Kemampuan komunikasi matematik, Contextual Teaching and Learning.

\section{ABSTRACT}

This research is motivated by the low mathematical communication skills of MA students. Therefore, an approach is needed to improve the mathematical communication skills of MA students. The purpose of the study is to examine and improve students' communication skills with contextual learning with Contextual Learning and Learning with students who are worthy of ordinary learning. This study was an experimental type with a pretest-posttest control group design. The population in this study were all students in one of the MA in Cimahi City, while the sample used a purposive sampling technique. The sample is X MIA as an experimental class as many as 20 students and class X IIS as a control class of 20 students. The instrument consisting of communication skills tests. The results showed that the achievement and improvement of mathematical communication skills of MA students who learned using Contextual Learning were better than those using ordinary learning.

Keywords: Mathematical communication skills, contextual teaching and learning.

\section{A. PENDAHULUAN}

Matematika merupakan ilmu universal yang mendasari teknologi modern dan mempunyai peranan penting dalam berbagai disiplin ilmu serta dapat membantu manusia dalam menyelesaikan permasalahan seharihari. Menurut Ruseffendi (2005:261), "Matematika adalah ratunya ilmu, maksudnya antara lain bahwa matematika itu tidak bergantung kepada bidang studi lain; matematika juga adalah pelayan ilmu". Sedangkan menurut depdiknas (Reba'i: 2014), "Matematika merupakan dasar terciptanya teknologi modern, karena teknologi modern akan tercipta jika seseorang memiliki penguasaan matematika yang kuat sejak dini”. Dari pernyataan di atas, matematika merupakan ilmu yang berdiri sendiri tetapi memiliki peranan penting bagi ilmu lainnya serta matematika 
merupakan ilmu dasar dalam terciptanya teknologi yang modern dan canggih.

Matematika juga merupakan disiplin ilmu yang wajib dipelajari mulai dari sekolah dasar, sekolah menengah pertama, sekolah menengah atas sampai perguruan tinggi. Oleh karena itu pada kurikulum 2013, pembelajaran matematika pada sekolah menengah atas memiliki jam yang lebih banyak dibandingkan dengan bidang studi lain. Hal ini sesuai dalam Kurikulum 2013 (Kurtilas) (Firmansyah, 2013), alasan matematika memiliki porsi jam lebih banyak dibandingkan mata pelajaran yang lain karena secara rinci tujuan pembelajaran matematika di sekolah,

1. Melatih cara berpikir
dan bernalar dalam menarik kesimpulan, misalnya melalui kegiatan penyelidikan, eksplorasi, eksperimen, dan lain-lain,

2. Mengembangkan aktivitas kreatif yang melibatkan imajinasi, intuisi, dan penemuan dengan mengembangkan pemikiran divergen, orisinil, rasa ingin tahu, membuat prediksi dan dugaan, serta mencoba-coba,

3. Mengembangkan

kemampuan memecahkan masalah,

4. Mengembangkan menyampaikan informasi atau mengkomunikasikan gagasan antara lain melalui pembicaraan lisan, grafik, peta, diagram, dalam menjelaskan gagasan tersebut,

Sedangkan menurut National Council of Teachers of Mathematics atau NCTM (Abdurahman, 2014:1), merumuskan tujuan pembelajaran matematika yaitu "(1) belajar untuk berkomunikasi (mathematical communication), (2) belajar untuk bernalar (mathematical reasoning), (3) belajar untuk memecahkan masalah (mathematical problem solving), (4) belajar untuk mengaitkan ide (mathematical connection),
(5) belajar untuk mempresentasikan ide-ide (mathematical representation)".

Dari keempat tujuan pembelajaran matematika pada Kurtilas di atas, tujuan pembelajaran yang harus dimiliki siswa adalah mengembangkan kemampuan menyampaikan informasi atau mengkomunikasikan gagasan antara lain melalui pembicaraan lisan, grafik, peta, diagram, dalam menjelaskan gagasan tersebut. Sedangkan dari tujuan pembelajaran matematika menurut NCTM, tujuan pembelajaran matematika yang harus dimiliki siswa adalah belajar untuk berkomunikasi (mathematical communication).

Salah satu tujuan yang ingin dicapai dalam keberhasilan pembelajaran matematika adalah kemampuan komunikasi matematik. Hal ini sejalan dengan pendapat Huinker dan Laughlin (Hulukati, 2005:5) bahwa salah satu tujuan yang ingin dicapai dalam pembelajaran matematika adalah memberikan kesempatan seluas-luasnya kepada para siswa untuk mengembangkan dan mengintegrasikan keterampilan berkomunikasi melalui lisan maupun tulisan serta mempresentasikan apa yang telah dipelajari. Selain itu, menurut Huang dan Normandia (Rohmah, 2013:14), "Komunikasi menjadi satu bagian penting dari matematika dan pembelajaran matematika. Penggunaan komunikasi berupa ucapan dan tulisan oleh guru dan siswa dalam pembelajaran matematika sangat penting untuk membangun mathematical thinking".

Namun kenyataan di lapangan, kemampuan komunikasi matematik masih rendah. Hal ini berdasarkan penelitian yang dilakukan oleh Hidayat (2009:82) bahwa kemampuan komunikasi matematik siswa sekolah menengah pada umumnya masih rendah. 
Hal ini ditunjukan dengan nilai tes siswa pada saat diberi soal tentang kemampuan komunikasi matematik.

Berdasarkan pemaparan diatas maka permasalahan yang timbul adalah bagaimana guru memilih metode pembelajaran yang cocok untuk mengembangkan kemampuan komunikasi dan disposisi matematik siswa. Suherman et al (Rohmah, 2013:5) mengatakan, "Guru seyogyanya memilih dan menggunakan strategi, pendekatan, metode, dan teknik yang dapat secara aktif melibatkan siswa dalam proses pembelajaran". Selanjutnya Suherman et al (Rohmah, 2013:5) mengungkapkan, "Siswa harus dibiasakan untuk diberi kesempatan bertanya dan berpendapat, sehingga diharapkan proses pembelajaran matematika lebih bermakna".

Pemilihan strategi, pendekatan, metode, dan teknik pembelajaran yang sesuai dapat mendorong siswa untuk lebih aktif, kreatif, dan mampu bernalar untuk mencapai kompetensi yang diharapkan. Keterlibatan siswa aktif saat pembelajaran berlangsung sangat diperlukan, karena dengan siswa aktif saat pembelajaran akan membuat pembelajaran menjadi lebih menyenangkan dan dapat meningkatkan wawasan. Hal ini senada dengan Ruseffendi (2006:2) yang mengemukakan, “... belajar dan atau bekerja dengan aktif itu lebih menyenangkan, bahwa belajar dengan aktif itu akan memperluas wawasan, dan lain-lain...".

Berdasarkan masalah di atas, diperlukan solusi dalam pembelajaran matematika baik strategi, pendekatan, metode maupun teknik pembelajaran yang sesuai yang hasilnya dapat meningkatkan kemampuan komunikasi matematik siswa menjadi lebih baik, melibatkan keaktifan siswa dalam pembelajaran matematika, membuat pembelajaran matematika menjadi lebih bermakna dan tidak membosankan, serta mengubah pandangan siswa terhadap pembelajaran matematika yang sulit menjadi mudah dan menyenangkan. Salah satu pendekatan yang berpeluang untuk meningkatkan kemampuan komunikasi siswa adalah pendekatan Contextual Teaching and Learning (CTL). Studi yang dilakukan oleh Bernard (2015) menunjukkan bahwa CTL merupakan peranan yang penting dalam meningkatkan kemampuan matematik siswa yang hasilnya dapat membantu siswa untuk meningkatkan prestasi siswa pada pembelajaran matematika.

Selain itu, Darmajari, Heriawan dan Senjaya (2012:23) mengemukakan bahwa dalam pendekatan kontekstual (Contextual Teaching and Learning/CTL) bahasa yang diajarkan dengan pendekatan komunikatif, yakni siswa di ajak menggunakan konteks nyata. Selain itu, dalam pendekatan CTL siswa bukan hanya mengembangkan kemampuan-kemampuan intelektual dan keterampilan tetapi juga aspek-aspek kepribadian seperti integritas pribadi, sikap, minat, tanggung jawab, dan sebagainya (Darmajari, Heriawan dan Senjaya, 2012:22). Masalah yang ditimbulkan dalam pendekatan ini dirancang agar siswa tertantang untuk komunikatif dan dapat memecahkan masalah dikehidupan sehari-hari.

Inti dari pendekatan CTL membantu guru mengaitkan antara materi yang diajarkannya dengan kehidupan nyata siswa (kehidupan sehari-hari). CTL menuntut siswa untuk dapat bekerja sama antar siswa dalam kelompok untuk mengungkapkan segala ide-ide yang dimilikinya. Selain itu, CTL juga menuntut siswa melalui pengalamannya belajar dapat menemukan sendiri materi yang harus dipahami, berusaha menemukan dan menciptakan hal baru dari apa yang dipelajari, serta dapat 
membangkitkan siswa agar siswa dapat menemukan sendiri materi yang dipelajarinya melalui pertanyaan-pertanyaan yang dikaitkan dengan kehidupan seharihari, melalui hal-hal tersebut diharapkan siswa dapat meningkatkan kemampuan komunikasi dalam kehidupan sehari-hari.

Hal inilah yang menarik penulis untuk mengambil kemampuan komunikasi menggunakan Contextual Teaching and Learning, karena dalam kegiatan pembelajarannya siswa dituntut untuk mengeksplorasi ide-ide baru dan mengungkapkan segala gagasan yang dimilikinya sebanyak mungkin tanpa dibatasi oleh aturan-aturan tertentu sehingga siswa diharapkan dapat mengkomunikasikan masalah yang disajikan guru melalui ide-ide dan gagasan yang ia.

Dari latar belakang permasalahan yang diuraikan di atas, maka peneliti bermaksud untuk melakukan penelitian dengan judul "Meningkatkan Kemampuan Komunikasi Matematik Siswa MA melalui Contextual Teaching and Learning".

\section{B. KAJIAN TEORI DAN METODE 1. Kemampuan Komunikasi Matematik}

Komunikasi dapat diartikan sebagai penyampaian pesan antara dua orang atau lebih agar pesan yang dimaksud dapat dipahami. Secara umum komunikasi merupakan proses penyampaian pesan atau berita dari pengirim pesan kepada penerima pesan baik secara ucapan (lisan) maupun tulisan untuk tujuan tertentu. Hal tersebut sesuai dengan pengertian komunikasi menurut Effendy (Rohaeti, 2003:10), "Proses penyampaian pesan oleh seseorang kepada orang lain untuk memberi tahu atau mengubah sikap, pendapat, atau perilaku baik langsung secara lisan maupun tak langsung melalui media”.
Dalam setiap pembelajaran akan terjadi peristiwa saling berhubungan atau saling berkomunikasi baik antara guru dan siswa maupun dengan sesama siswa. Pembelajaran matematika juga tidak terlepas dari komunikasi. Komunikasi pada pembelajaran matematika sangatlah penting, hal ini dikemukakan Baroody (Sumarmo, 2012:14), ada dua alasan penting mengapa pembelajaran matematika berfokus pada komunikasi,

a. Matematika adalah bahasa essensial yang tidak hanya sebagai alat berpikir, menemukan rumus, menyelesaikan masalah, atau menyimpulkan saja, namun matematika juga memiliki nilai yang tak terbatas untuk menyatakan beragam idea secara jelas, teliti dan tepat,

b. Matematika dan mempelajari matematika adalah jantungnya kegiatan manusia, misalnya dalam pembelajaran matematika interaksi antara guru dan siswa, antara siswa dan siswa, antara bahan pembelajaran matematika dan siswa adalah faktor-faktor penting dalam memajukan potensi siswa.

Peranan penting lainnya mengapa pembelajaran matematika berfokus pada komunikasi juga dikemukakan oleh Asikin (Sumarmo, 2012:14), "Membantu siswa menajamkan cara berpikir, sebagai alat untuk menilai pemahaman siswa, membantu siswa mengorganisasi pengetahuan matematik, membantu siswa membangun pengetahuan matematiknya, meningkatkan kemampuan pemecahan masalah, memajukan penalaran, membangun kemampuan diri, meningkatkan keterampilan sosialnya, serta bermanfaat dalam komunitas matematik".

Kemampuan komunikasi siswa dapat ditingkatkan melalui berbagai cara, diantaranya dengan melakukan diskusi kelompok di dalam kelas. Dalam diskusi 
kelompok, siswa dikelompokkan menjadi kelompok-kelompok kecil yang heterogen kemampuannya. Di dalam kelompok, siswa mendapatkan kesempatan untuk mengemukakan ide dan pendapatnya mengenai permasalahan yang diberikan guru dan dapat bertukar pemikiran antar teman dalam satu kelompok. Hal ini yang dapat mengembangkan dan meningkatkan kemampuan komunikasi siswa karena siswa terbiasa mengemukakan ide dan pendapatnya dalam diskusi kelompok.

Menurut NCTM (Fajriani, 2016:13), komunikasi matematik adalah kemampuan siswa untuk menyatakan ide-ide matematika baik secara lisan maupun tertulis. Sedangkan menurut Greenes dan Schulman (Zanthy, 2011:17), komunikasi matematik merupakan,

a. Kekuatan sentral bagi siswa dalam merumuskan konsep dan strategi,

b. Modal keberhasilan bagi siswa terhadap pendekatan dan penyelesaian dalam eksplorasi dan investigasi matematika,

c. Wadah bagi siswa dalam berkomunikasi dengan teman-temannya untuk memperoleh informasi, berbagi pikiran dan penemuan, curah pendapat, menilai dan mempertajam ide untuk meyakinkan yang lain.

Berdasarkan uraian di atas, komunikasi adalah penyampaian pesan kepada seseorang baik secara lisan maupun tertulis untuk tujuan tertentu Sedangkan kemampuan komunikasi matematik adalah kemampuan siswa untuk menyampaikan pesan yang diketahuinya, baik pesan berupa konsep, rumus, maupun strategi penyelesaian suatu masalah matematika.

Untuk melihat kemampuan komunikasi matematik yang dimiliki siswa dapat dilihat dari indikator-indikator kemampuan komunikasi pada pembelajaran matematika.
Indikator kemampuan komunikasi matematik menurut Sumarmo (2012:14),

a. Menghubungkan benda nyata, gambar, dan diagram ke dalam ide matematik,

b. Menjelaskan ide, situasi dan relasi matematik secara lisan dan tulisan dengan benda nyata, gambar, grafik dan aljabar,

c. Menyatakan peristiwa sehari-hari dalam bahasa atau simbol matematik,

d. Mendengarkan, berdiskusi, dan menulis tentang matematika,

e. Membaca dengan pemahaman suatu presentasi matematika,

f. Menyusun konjektur, menyusun argumen, merumuskan definisi dan generalisasi,

g. Mengungkapkan kembali suatu uraian atau paragrap matematika dengan bahasa sendiri.

Sedangkan indikator kemampuan komunikasi matematik menurut Susilawati (2014:201),

a. Menghubungkan benda nyata, gambar, dan diagram ke dalam ide matematika,

b. Menjelaskan ide, situasi dan relasi matematik, secara lisan atau tulisan, dengan benda nyata, gambar, grafik dan aljabar,

c. Menyatakan peristiwa sehari-hari dengan bahasa matematika,

d. Mendengarkan, diskusi, dan menulis tentang matematika,

e. Membaca dengan pemahaman suatu presentasi matematika tertulis,

f. Menyusun pertanyaan matematika yang relevan dengan situasi masalah,

g. Membuat konjektur, menyusun argumen, merumuskan definisi dan generalisasi.

Indikator kemampuan komunikasi matematik yang digunakan pada penelitian ini adalah menghubungkan gambar ke dalam ide matematika; menjelaskan ide, situasi dan relasi matematik secara tulisan dengan 
gambar, dan aljabar; menyatakan peristiwa sehari-hari dengan bahasa matematika.

\section{Contextual Teaching and Learning}

Mulyasa (Hartono, 2014:83) mengatakan, "CTL (Contextual Teaching and Learning) merupakan konsep pembelajaran yang menekankan pada keterkaitan antara materi pembelajaran dengan dunia kehidupan peserta didik dengan nyata, sehingga para peserta didik mampu menghubungkan dan menerapkan kompetensi hasil belajar dalam kehidupan sehari-hari". Menurut Hartono (2014:83), "Strategi pembelajaran kontekstual (Contextual Teaching and Learning/CTL) merupakan strategi pembelajaran yang menekankan pada proses keterlibatan siswa secara penuh dalam menemukan materi dan hubungannya dalam proses pembelajaran".

Sedangkan menurut Darmajari, Heriawan dan Senjaya (2012:19) pembelajaran kontekstual (Contextual Teaching and Learning/CTL) merupakan, suatu proses pendidikan yang holistik dan bertujuan memotivasi siswa untuk memahami makna materi pelajaran yang dipelajarinya dengan mengkaitkan materi tersebut dengan konteks kehidupan sehari-hari (konteks pribadi, sosial, dan kultural) sehingga siswa memiliki pengetahuan/keterampilan yang secara fleksibel dapat diterapkan (ditransfer) dari suatu permasalahan/konteks ke permasalahan/konteks lainnya.

Dari uraian di atas, CTL merupakan suatu konsep belajar di mana guru menghadirkan situasi dunia nyata ke dalam kelas dan memotivasi siswa membuat hubungan antara pengetahuan yang dimilikinya dengan penerapannya dalam kehidupan sehari-hari. Dalam pembelajaran CTL siswa diminta terlibat aktif dalam setiap proses pembelajaran.
Menurut Susilawati (2014:136), pembelajaran kontekstual terdiri dari tujuh fase,

a. Kontruktivisme adalah proses membangun atau menyusun pengetahuan baru dalam struktur kognitif siswa berdasarkan pengalaman, melalui keterlibatan aktif siswa selama proses pembelajaran,

b. Experiencing yaitu, belajar menemukan sendiri materi yang harus dipahami, berusaha menemukan dan menciptakan hal baru dari apa yang dipelajari,

c. Questioning, membangkitkan siswa agar siswa dapat menemukan sendiri materi yang dipelajarinya melalui pertanyaanpertanyaan,

d. Learning community, belajar merupakan proses kolaborasi secara kelompok, masyarakat belajar,

e. Modelling yaitu siswa memperagakan konsep yang abstrak secara konkrit,

f. Reflection yaitu menganalisis kembali pengalamannya sendiri sehingga siswa dapat menyimpulkan tentang pengalaman belajarnya,

g. Authentic assessment yaitu penilaian dari proses awal hingga selesai berlangsungnya kegiatan belajar mengajar.

\section{Metodologi}

Metode penelitian ini menggunakan pendekatan kuantitatif yaitu jenis penelitian yang menggunakan rancangan penelitian berdasarkan prosedur statistik atau dengan cara lain dari kuantifikasi untuk mengukur variabel penelitiannya. Metode kuantitatif penelitian ini adalah metode kuasi eksperimen. Pada kuasi eksperimen subjek tidak dikelompokkan secara acak, tetapi peneliti menerima keadaan subjek seadanya. Ruseffendi (2010:74) menyatakan bahwa untuk rancangan Quasi-Experimental dengan desain non equivalen pretest and 
posttest control group design. Kedua kelompok tersebut sama-sama memperoleh pretes dan postes, akan tetapi kelompok eksperimen saja yang diberikan perlakuan (treatment). Pembelajaran pada kelas eksperimen menggunakan pendekatan Contextual Teaching and Learning, sedangkan pembelajaran pada kelas kontrol menggunakan pembelajaran biasa. Desain penelitian dengan mengunakan metode kuasi eksperimen menurut Ruseffendi (2005) adalah sebagai berikut:

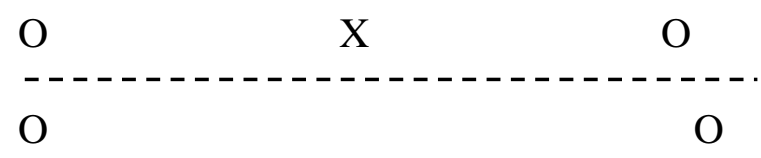

Keterangan:

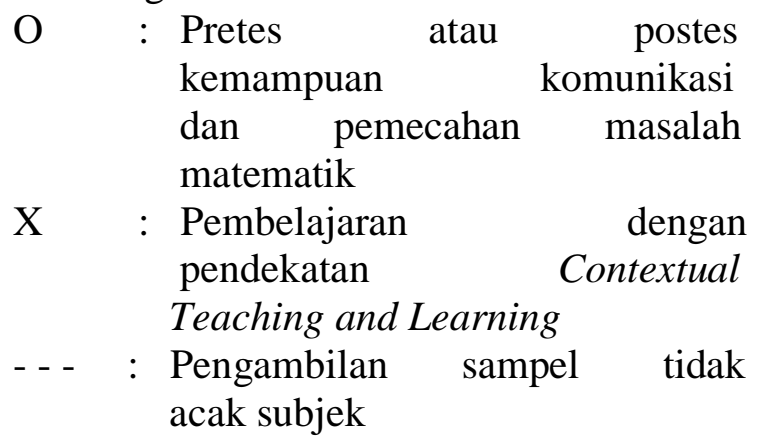

Populasi dalam penelitian ini adalah seluruh siswa di salah satu MA di Kota Cimahi. Peneliti memilih sekolah ini karena menurut Kepala Seksi Kurikulum, kemampuan sekolah ini berada di atas rata-rata dan juga siswa di sekolah tersebut sudah dapat,

a. Mengaitkan konsep-konsep yang dimilikinya ke dalam peristiwa seharihari,

b. Mengaitkan konsep-konsep sebelumnya dengan konsep yang akan diajarkan,

c. Siswa sudah lebih mandiri untuk belajar menemukan sendiri materi yang harus dipahami, berusaha menemukan dan menciptakan hal baru dari apa yang dipelajari, dibantu oleh guru sebagai fasilitator.
Penelitian ini dilakukan di MA MT Asih Putera. Di sekolah tersebut terdapat dua kelas X, ditentukan kelas eksperimen dan kontrol. Penentuan kelas eksperimen dan kontrol dengan menggunakan teknik purposive sampling yaitu dengan pertimbangan bahwa penyebaran siswa untuk kedua kelas tersebut merata di tinjau dari segi kemampuan akademisnya. Dalam hal ini kepala sekolah dan guru matematika yang mengajar sebagai penimbang. Berdasarkan teknik tersebut, sampel pada penelitian yaitu kelas X MIA sebagai kelas eksperimen sebanyak 20 siswa dan kelas X IIS sebagai kelas kontrol sebanyak 20 siswa.

Penelitian ini bertujuan untuk melihat pencapaian dan peningkatan kemampuan komunikasi matematik siswa MA yang pembelajarannya mneggunakan Contextual Teaching and Learning dengan yang menggunakan pembelajaran biasa. Instrumen pada penelitian ini adalah tes untuk mengukur kemampuan komunikasi matematik siswa untuk materi trigonometri. Banyak soal pada tes komunikasi matematik adalah lima soal dengan SMI (Skor Maksimal Idel) adalah 42.

\section{HASIL PENELITIAN DAN PEMBAHASAN}

Adapun hasil rekapitulasi deskriptif data hasil penelitian adalah sebagai berikut:

\section{Tabel 1}

Rekapitulasi Nilai Kemampuan Komunikasi dan Disposisi Matematik

\begin{tabular}{|c|c|c|c|c|c|c|c|}
\hline \multirow{2}{*}{} & \multirow{2}{*}{ Statistik } & \multicolumn{3}{|c|}{$\begin{array}{c}\text { Contextual } \\
\text { Teaching } \\
\text { And } \\
\text { Learning } \\
\text { (N =20) }\end{array}$} & \multicolumn{3}{|c|}{$\begin{array}{c}\text { Pembelajaran } \\
\text { Biasa } \\
\text { (N =20) }\end{array}$} \\
\cline { 3 - 8 } & Pretes & Postes & $\begin{array}{c}\text { N- } \\
\text { Gain }\end{array}$ & Pretes & Postes & $\begin{array}{c}\text { N- } \\
\text { Gai } \\
\text { n }\end{array}$ \\
\hline \multirow{2}{*}{$\begin{array}{c}\text { Komunik } \\
\text { asi } \\
\text { SMI 42 }\end{array}$} & $\bar{x}$ & 6,40 & 28,80 & 0,63 & 6,40 & 18,65 & 0,35 \\
\cline { 2 - 8 } & & 15,24 & 68,58 & & 15,24 & 44,40 & \\
\cline { 2 - 8 } & & 2,78 & 9,92 & & 2,01 & 8,45 & \\
\hline
\end{tabular}


SMI (Skor Maksimal Ideal)

\section{Analisis Kemampuan Komunikasi Matematik Berdasarkan Pendekatan Pembelajaran}

a. Analisis Data Pretes Kemampuan Komunikasi Matematik

Sebelum perlakuan terhadap kedua kelas diberikan, terlebih dahulu dilakukan pretes. Tujuannya untuk mengetahui kemampuan awal komunikasi matematik siswa kelas eksperimen dan kelas kontrol, sehingga dapat diketahui kemampuan awal kedua kelas secara garis besar sama atau tidak. Untuk analisis statistik dari data pretes dilakukan dengan menggunakan software IBM SPSS Statistics 20. Berikut hasil deskripsi statistik skor pretes kemampuan komunikasi matematik,

Tabel 2

Deskripsi Statistik Skor Pretes Kemampuan Komunikasi Matematik

\begin{tabular}{|c|c|c|c|c|c|}
\hline \multirow{2}{*}{$\begin{array}{c}\text { Skor } \\
\text { Pretes }\end{array}$} & Kelas & N & Rerata & $\%$ & $\begin{array}{c}\text { Std. } \\
\text { Deviasi }\end{array}$ \\
\cline { 2 - 6 } & Eksperimen & 20 & 6,40 & 15,24 & 2,78 \\
\cline { 2 - 6 } & Kontrol & 20 & 6,40 & 15,24 & 2,01 \\
\hline
\end{tabular}

Berdasarkan Tabel 2 di atas menunjukkan bahwa rata-rata kemampuan awal komunikasi matematik siswa kelas eksperimen dan kelas kontrol adalah 6,40. Terlihat bahwa rata-rata skor kemampuan awal siswa kelas eksperimen sama. Untuk mengetahui apakah terdapat perbedaan yang signifikan atau tidak antara kelas eksperimen dan kelas kontrol dilakukan uji statistic sebagai berikut:

\section{1) Uji Normalitas}

Uji normalitas data dilakukan untuk mengetahui apakah sampel yang berasal dari populasi yang berdistribusi normal atau tidak berdistribusi normal. Uji normalitas yang digunakan adalah uji KolmogorovSmirnov dengan taraf signifikan 5\%.
Adapun kriteria pengujiannya adalah sebagai berikut:

Jika Sig. $>0,05$, maka sampel berasal dari populasi yang berdistribusi normal

Jika Sig. $\leq 0,05$, maka sampel berasal dari populasi yang tidak berdistribusi normal

Selanjutnya dilakukan penskoran terhadap pretes yang telah diberikan pada masingmasing kelas untuk dianalisis menggunakan software IBM SPSS Statistics 20. Berikut ini disajikan hasil pengolahan data uji normalitas data pretes kelas eksperimen dan pretes kelas kontrol,

Tabel 3

Uji Normalitas Data Pretes Kemampuan Komunikasi Matematik

\begin{tabular}{|c|c|c|c|c|c|}
\hline & \multirow{2}{*}{ Kelas } & \multicolumn{3}{|c|}{ Kolmogorov-Smirnova } & \multirow{2}{*}{ Ket. } \\
\hline & & Statistic & df & Sig. & \\
\hline \multirow{2}{*}{$\begin{array}{c}\text { Skor Pretes } \\
\text { Kemampuan } \\
\text { Komunikasi } \\
\text { Matematik }\end{array}$} & CTL & 257 & 20 & .001 & $\begin{array}{c}\text { Tidak } \\
\text { berdistribusi } \\
\text { normal }\end{array}$ \\
\hline & $\begin{array}{c}\text { Pembelajaran } \\
\text { Biasa }\end{array}$ & .183 & 20 & .079 & $\begin{array}{c}\text { Berdistribusi } \\
\text { normal }\end{array}$ \\
\hline
\end{tabular}
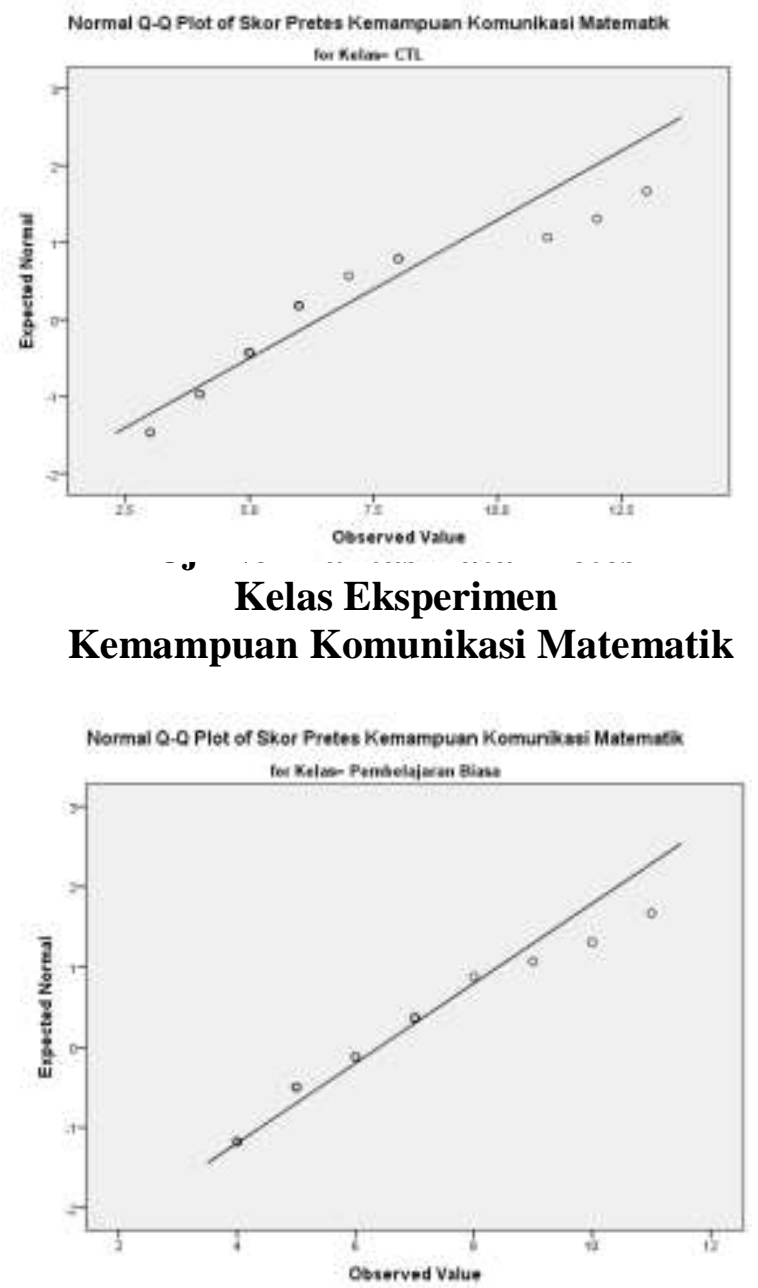


\section{Gambar 2 \\ Uji Normalitas Data Pretes Kelas Kontrol Kemampuan Komunikasi Matematik}

Berdasarkan data pada Tabel 3 terlihat bahwa Sig. pada kelas ekperimen adalah 0,001 dan kelas kontrol 0,079. Pada kelas eksperimen memenuhi kriteria Sig. $<0,05$ yang artinya sampel berasal dari populasi yang tidak berdistribusi normal. Pada kelas kontrol memenuhi kriteria Sig. $\geq 0,05$ yang artinya sampel berasal dari populasi yang berdistribusi normal. Senada dengan data pada Tabel 3, hal ini terlihat pada Gambar 1 terlihat jelas bahwa titik-titik tidak berada di sekitar garis lurus yang mengartikan sampel berasal dari populasi yang tidak berdistribusi normal. Sedangkan pada Gambar 2 terlihat jelas bahwa titik-titik berada di sekitar garis lurus yang mengartikan sampel berasal dari populasi yang berdistribusi normal. Berdasarkan pengujian tersebut karena kelas kontrol berasal dari populasi yang berdistribusi normal sedangkan kelas eksperimen berasal dari populasi yang tidak berdistribusi normal maka pengujian ini dapat disimpulkan kedua kelas tidak berdistribusi normal akibatnya tidak dilakukan uji homogenitas varians akan tetapi dilakukan uji dua rerata menggunakan uji Mann-Whitney.

\section{2) Uji Mann-Whitney}

Berdasarkan hasil uji normalitas diperoleh bahwa salah satu kelas berasal dari sampel yang tidak berdistribusi normal, maka pengujian selanjutnya untuk data pretes kemampuan komunikasi menggunakan uji Mann-Whitney. Menurut Ramachandran \&
Tsoko (2009:672), hipotesis statistiknya dirumuskan sebagai berikut:

$\begin{aligned} \mathrm{H}_{0}: \mathrm{m}_{1}=\mathrm{m}_{2} & \text { (Tidak terdapat perbedaan } \\ & \text { kemampuan } \\ & \text { komunikasi matematik } \\ & \text { siswa MA antara yang } \\ & \text { pembelajarannya } \\ & \text { menggunakan Contextual } \\ & \text { Teaching and Leaning } \\ & \text { dengan yang } \\ & \text { menggunakan } \\ & \text { pembelajaran biasa) } \\ \mathrm{H}_{1}: \mathrm{m}_{1} \neq \mathrm{m}_{2} & \text { Terdapat perbedaan } \\ & \text { kemampuan awal } \\ & \text { komunikasi matematik } \\ & \text { siswa MA antara yang } \\ & \text { pembelajarannya } \\ & \text { menggunakan Contextual } \\ & \text { Teaching and Leaning } \\ & \text { dengan yang } \\ & \text { menggunakan } \\ & \text { pembelajaran biasa) }\end{aligned}$

Keterangan:

\begin{tabular}{rlrr}
$\mathrm{m}_{1}:$ & median & skor & \multicolumn{1}{c}{ pretes } \\
& kemampuan & & komunikasi \\
& matematik & kelas & yang \\
& pembelajarannya & & menggunakan \\
& Contextual Teaching and Leaning \\
$\mathrm{m}_{2}:$ & median & skor & pretes \\
& kemampuan & & komunikasi \\
& matematik & kelas & yang \\
& pembelajarannya & & menggunakan \\
& pembelajaran biasa & &
\end{tabular}

Adapun kriteria pengujiannya sebagai berikut:

Jika Sig. $>0,05$ maka $\mathrm{H}_{0}$ diterima

Jika Sig. $\leq 0,05$, maka $\mathrm{H}_{0}$ ditolak

Berikut adalah tabel hasil pengujian dengan menggunakan software IBM SPSS Statistics 20 ,

\section{Tabel 4}

Uji Mann-Whitney Data Pretes

Kemampuan Komunikasi Matematik 


\begin{tabular}{|c|c|c|}
\hline & $\begin{array}{c}\text { Kemampuan } \\
\text { Komunikasi } \\
\text { Matematik }\end{array}$ & \\
\hline Mann-Whitney U & 184.500 & \multirow{5}{*}{$\mathrm{H}_{0}$ diterima } \\
\hline Wilcoxon W & 394.500 & \\
\hline $\mathrm{Z}$ & -.425 & \\
\hline $\begin{array}{l}\text { Asymp. Sig. (2- } \\
\text { tailed) }\end{array}$ & .671 & \\
\hline $\begin{array}{l}\text { Exact Sig. [2*(1- } \\
\text { tailed Sig.)] }\end{array}$ & $.678^{\mathrm{b}}$ & \\
\hline
\end{tabular}

Berdasarkan Tabel 4 terlihat bahwa statistika uji $\mathrm{Z}=-0,425$ dengan Sig. (2tailed) nilai Sig. $0,671>0,05$. Sesuai dengan kriteria pengujian maka $\mathrm{H}_{0}$ diterima artinya tidak terdapat perbedaan kemampuan awal komunikasi matematik siswa MA antara yang pembelajarannya menggunakan Contextual Teaching and Learning dengan yang menggunakan pembelajaran biasa.

\section{b. Analisis Data Postes Kemampuan Komunikasi Matematik}

Hasil analisis data postes digunakan untuk melihat pencapaian kemampuan komunikasi matematik kelas eksperimen dan kelas kontrol. Berikut hasil deskripsi statistik skor postes kemampuan komunikasi matematik,

\section{Tabel 5}

\section{Deskripsi Statistik DataPostes}

Kemampuan Komunikasi Matematik

\begin{tabular}{|l|c|c|c|c|c|}
\hline \multirow{2}{*}{$\begin{array}{l}\text { Skor } \\
\text { Postes }\end{array}$} & Kelas & N & Rerata & \% & $\begin{array}{c}\text { Std. } \\
\text { Deviasi }\end{array}$ \\
\cline { 2 - 6 } & Eksperimen & 20 & 28,80 & 68,58 & 9,92 \\
\cline { 2 - 6 } & Kontrol & 20 & 18,65 & 44,40 & 8,45 \\
\hline
\end{tabular}

Berdasarkan Tabel 5, rata-rata kemampuan komunikasi matematik siswa kelas eksperimen setelah diberikan CTL adalah 28,80 atau sekitar $68,58 \%$, sedangkan ratarata kemampuan komunikasi matematik siswa kelas kontrol setelah diberikan pembelajaran biasa adalah 18,65 atau sekitar $44,40 \%$. Terlihat bahwa secara umum ratarata skor postes siswa kelas eksperimen lebih besar daripada kelas kontrol, namun masih berada pada kualifikasi sedang. Untuk mengetahui apakah pencapaian kemampuan komunikasi matematik siswa kelas eksperimen dan kelas kontrol berbeda secara signifikan atau tidak maka dilakukan uji statistik sebagai berikut:

\section{1) Uji Normalitas}

Adapun kriteria pengujiannya adalah sebagai berikut:

Jika Sig. $>0,05$, maka sampel berasal dari populasi yang berdistribusi normal

Jika Sig. $\leq 0,05$, maka sampel berasal dari populasi yang tidak berdistribusi normal.

Selanjutnya, dilakukan penskoran terhadap postes yang telah diberikan pada masingmasing kelas untuk dianalisis menggunakan software IBM SPSS Statistics 20. Berikut ini disajikan hasil pengolahan data uji normalitas data postes kelas eksperimen dan postes kelas kontrol,

Tabel 6

Uji Normalitas Data Postes

Kemampuan Komunikasi Matematik

\begin{tabular}{|c|c|c|c|c|c|}
\hline & \multirow{2}{*}{ Kelas } & \multicolumn{3}{|c|}{ Kolmogorov-Smirnov $^{a}$} & \multirow{2}{*}{ Ket. } \\
\hline & & Statistic & df & Sig. & \\
\hline \multirow{2}{*}{$\begin{array}{c}\text { Skor } \\
\text { Postes } \\
\text { Kemampuan } \\
\text { Komunikasi } \\
\text { Matematik }\end{array}$} & CTL & .184 & 20 & .075 & $\begin{array}{c}\text { Berdistribusi } \\
\text { normal }\end{array}$ \\
\hline & $\begin{array}{c}\text { Pemb } \\
\text { Biasa } \\
\end{array}$ & .217 & 20 & .014 & $\begin{array}{c}\text { Tidak } \\
\text { berdistribusi } \\
\text { normal }\end{array}$ \\
\hline
\end{tabular}

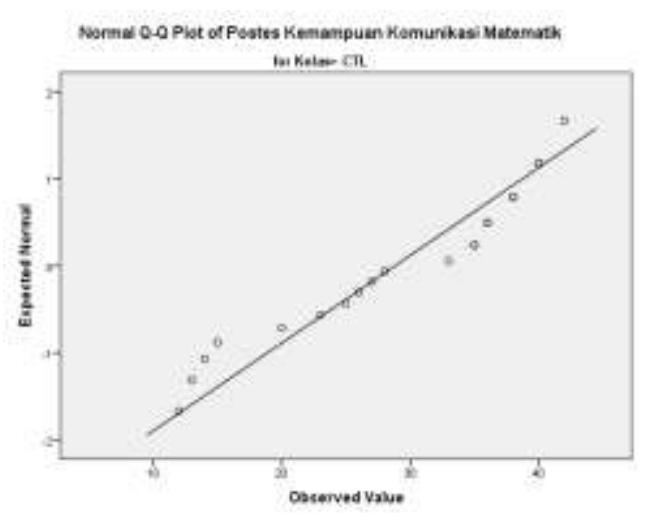

Gambar 3 Uji Normalitas Data Postes Kelas Eksperimen Kemampuan Komunikasi Matematik 


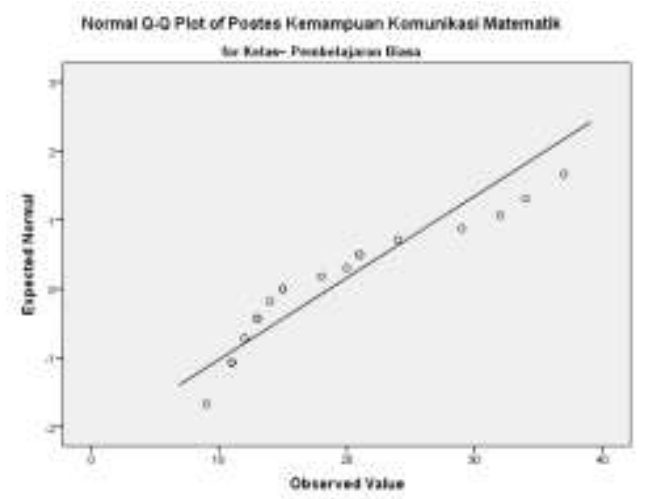

\section{Gambar 4Uji Normalitas Data Postes Kelas Kontrol Kemampuan Komunikasi Matematik}

Berdasarkan data pada Tabel 6 terlihat bahwa Sig. pada kelas ekperimen adalah 0,075 dimana nilai tersebut memenuhi kriteria Sig. > 0,05 yang artinya sampel berasal dari populasi yang berdistribusi normal. Sedangkan kelas kontrol 0,014 dimana nilai tersebut memenuhi kriteria Sig. $\leq 0,05$ yang artinya sampel berasal dari populasi yang tidak berdistribusi normal. Senada dengan data pada Tabel 6, hal tersebut pun dipertegas dengan Gambar 3 terlihat jelas bahwa titik-titik berada di sekitar garis lurus yang mengartikan sampel berasal dari populasi yang berdistribusi normal. Berbeda halnya dengan Gambar 4 terlihat jelas bahwa titik-titik tidak berada di sekitar garis lurus yang mengartikan sampel berasal dari populasi yang tidak berdistribusi normal. Berdasarkan pengujian tersebut karena kelas kontrol berasal dari populasi yang tidak berdistribusi normal maka pengujian ini dapat disimpulkan kedua kelas tidak berdistribusi normal akibatnya tidak dilakukan uji homogenitas varians akan tetapi dilakukan uji dua rerata menggunakan uji Mann-Whitney.

\section{2) Uji Mann-Whitney}

Berdasarkan hasil uji normalitas diperoleh bahwa salah satu kelas berasal dari sampel yang tidak berdistribusi normal, maka pengujian selanjutnya untuk data postes kemampuan komunikasi dengan menggunakan uji Mann-Whitney. Menurut Ramachandran \& Tsoko (2009:672), hipotesis statistiknya dirumuskan sebagai berikut:

$\mathrm{H}_{0}: \mathrm{m}_{1}=\mathrm{m}_{2}$ (Tidak terdapat perbedaan pencapaian kemampuan komunikasi matematik siswa MA antara yang pembelajarannya menggunakan Contextual Teaching and Leaning dengan yang menggunakan pembelajaran biasa)

$\mathrm{H}_{1}: \mathrm{m}_{1}>\mathrm{m}_{2}$ (Pencapaian kemampuan komunikasi matematik siswa MA antara yang pembelajarannya

menggunakan Contextual Teaching and Leaning lebih baik daripada yang menggunakan pembelajaran biasa)

Keterangan:

$\mathrm{m}_{1}$ : median skor postes kemampuan komunikasi matematik kelas yang pembelajarannya menggunakan Contextual Teaching and Leaning

$\mathrm{m}_{2}$ : median skor postes kemampuan komunikasi matematik kelas yang pembelajarannya menggunakan pembelajaran biasa

Nilai Sig. harus dibagi dua karena dengan menggunakan software IBM SPSS Statistics 20 dimana nilai Sig. dilakukan untuk melihat uji dua pihak. Sedangkan yang digunakan pada pengujian ini untuk memihak kepada salah satu pihak sebagaimana hipotesis penelitian. Menurut Uyanto (2009:145) bahwa tampilan signifikan dari SPSS adalah untuk uji dua pihak (2-tailed), karena kita akan melakukan uji hipotesis satu pihak (1tailed) maka nilai Sig. (2-tailed) harus dibagi dua. Kriteria pengujiannya, yaitu: 
Jika Sig. $(1$-tailed $)=\frac{1}{2} \times$ Sig. $(2$-tailed $)>$ 0,05 maka $\mathrm{H}_{0}$ diterima

Jika Sig. (1-tailed $)=\frac{1}{2} \times$ Sig. $(2$-tailed $) \leq$ 0,05 maka $\mathrm{H}_{0}$ ditolak

Berikut adalah tabel hasil pengujian dengan menggunakan software IBM SPSS Statistics 20 ,

\section{Tabel 7}

Uji Mann-Whitney Data Postes Kemampuan Komunikasi Matematik

\begin{tabular}{|l|r|r|}
\hline & \multicolumn{1}{|c|}{$\begin{array}{c}\text { Skor Postes } \\
\text { Kemampuan } \\
\text { Komunikasi Matematik }\end{array}$} & \multirow{2}{*}{ Interpretasi } \\
\hline Mann-Whitney U & 85.000 & \\
\hline Wilcoxon W & 295.000 & \multirow{2}{*}{$\mathrm{H}_{0}$ ditolak } \\
\hline $\mathrm{Z}$ & -3.115 & \\
\cline { 1 - 2 } $\begin{array}{l}\text { Asymp. Sig. (2- } \\
\text { tailed) }\end{array}$ & .002 & \\
\hline $\begin{array}{l}\text { Exact Sig. [2*(1- } \\
\text { tailed Sig.)] }\end{array}$ & $.001^{\mathrm{b}}$ & \\
\hline
\end{tabular}

Berdasarkan data pada Tabel 7 terlihat bahwa statistika uji $\mathrm{Z}=-3,115$ dengan Sig. (2-tailed) adalah 0,002 sehingga Sig. (1tailed) menjadi $\frac{0,002}{2}=0,001$, nilai tersebut memenuhi kriteria Sig. (1-tailed) $\leq 0,05$ maka $\mathrm{H}_{0}$ ditolak yang artinya pencapaian kemampuan komunikasi matematik siswa MA yang pembelajarannya menggunakan Contextual Teaching and Learning lebih baik daripada yang menggunakan pembelajaran biasa.

\section{c. Analisis Data N-Gain Kemampuan Komunikasi Matematik}

Setelah didapat skor pretes dan skor postes kemampuan komunikasi matematik, kemudian dilakukan pengolahan data skor gain ternormalisasi. Data gain ternormalisasi diolah untuk melihat peningkatan kemampuan komunikasi matematik siswa pada setiap kelompok kelas. Berikut deskripsi statistik data $\mathrm{N}$-Gain kemampuan komunikasi matematik,

\section{Tabel 8}

\section{Deskripsi Statistik Skor N-Gain}

Kemampuan Komunikasi Matematik

\begin{tabular}{|c|c|c|c|c|c|}
\hline \multirow{2}{*}{$\begin{array}{c}\text { Skor } \\
\text { N- } \\
\text { Gain }\end{array}$} & Kelas & N & Rerata & \% & $\begin{array}{c}\text { Std. } \\
\text { Deviasi }\end{array}$ \\
\cline { 2 - 6 } & Eksperimen & 20 & 0,63 & 63,08 & 0,27 \\
\cline { 2 - 6 } & Kontrol & 20 & 0,35 & 34,74 & 0,23 \\
\hline
\end{tabular}

Berdasarkan Tabel 8 terlihat bahwa rerata nilai $\mathrm{N}$-Gain pada kelas eksperimen adalah 0,63 dan kelas kontrol adalah 0,35 hal ini menunjukan bahwa terdapat perbedaan peningkatan kemampuan komunikasi matematik siswa. Sama halnya dengan data pretes dan postes, data gain ternormalisasi juga harus dianalisis, adapun langkahlangkah untuk mengolah data gain ternormalisasi sebagai berikut:

\section{1) Uji Normalitas}

Adapun kriteria pengujiannya adalah sebagai berikut:

Jika Sig. > 0,05, maka sampel berasal dari populasi yang berdistribusi normal

Jika Sig. $\leq$ 0,05, maka sampel berasal dari populasi yang tidak berdistribusi normal

Selanjutnya, dilakukan penskoran terhadap $\mathrm{N}$-Gain yang telah diberikan pada masingmasing kelas untuk dianalisis menggunakan software IBM SPSS Statistics 20. Berikut ini disajikan hasil pengolahan data uji normalitas data pretes kelas eksperimen dan pretes kelas kontrol,

\section{Tabel 9}

Uji Normalitas Data N-Gain Kemampuan Komunikasi Matematik

\begin{tabular}{|c|c|c|c|c|c|}
\hline & \multirow{2}{*}{ Kelas } & \multicolumn{3}{|c|}{ Kolmogorov-Smirnov } & \multirow{2}{*}{ Ket. } \\
\hline & & Statistic & df & Sig. & \\
\hline \multirow{2}{*}{$\begin{array}{c}\text { N-Gain } \\
\text { Kemampuan } \\
\text { Komunikasi } \\
\text { Matematik }\end{array}$} & CTL & .166 & 20 & .149 & $\begin{array}{c}\text { Berdistribusi } \\
\text { normal }\end{array}$ \\
\hline & $\begin{array}{l}\text { Pemb. } \\
\text { Biasa }\end{array}$ & .198 & 20 & .039 & $\begin{array}{c}\text { Tidak } \\
\text { berdistribusi } \\
\text { normal }\end{array}$ \\
\hline
\end{tabular}

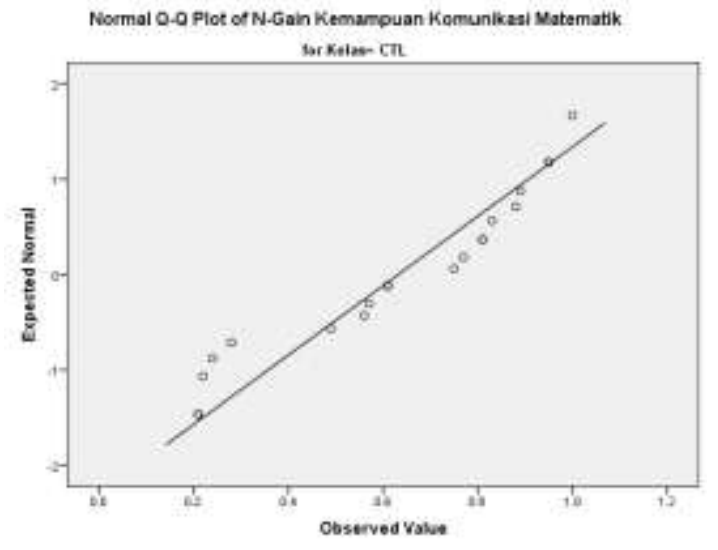




\section{Gambar 5 \\ Uji Normalitas Data N-Gain Kelas Eksperimen Kemampuan Komunikasi Matematik}

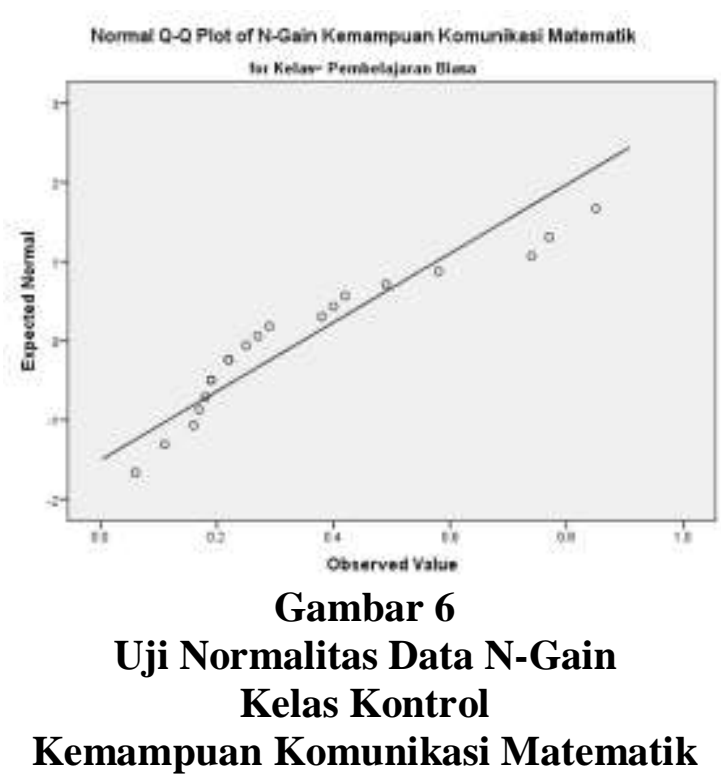

Berdasarkan data pada Tabel 9 terlihat bahwa Sig. pada kelas ekperimen adalah 0,149 dimana nilai tersebut memenuhi kriteria Sig. > 0,05 yang artinya sampel berasal dari populasi yang berdistribusi normal. Sedangkan kelas kontrol 0,039 dimana nilai tersebut memenuhi kriteria Sig. $\leq 0,05$ yang artinya sampel berasal dari populasi yang tidak berdistribusi normal. Senada dengan data pada Tabel 9, hal tersebut pun dipertegas dengan Gambar 5 terlihat jelas bahwa titik-titik berada di sekitar garis lurus yang mengartikan sampel berasal dari populasi yang berdistribusi normal. Berbeda halnya dengan Gambar 6 terlihat jelas bahwa titik-titik tidak berada di sekitar garis lurus yang mengartikan sampel berasal dari populasi yang tidak berdistribusi normal. Berdasarkan pengujian tersebut karena kelas kontrol berasal dari populasi yang tidak berdistribusi normal maka pengujian ini dapat disimpulkan kedua kelas tidak berdistribusi normal akibatnya tidak dilakukan uji homogenitas varians akan tetapi dilakukan uji dua rerata menggunakan uji Mann-Whitney.

\section{2) Uji Mann-Whitney}

Berdasarkan hasil uji normalitas diperoleh bahwa salah satu kelas berasal dari sampel yang tidak berdistribusi normal, maka pengujian selanjutnya untuk data $\mathrm{N}$ Gain kemampuan komunikasi dengan menggunakan uji Mann- Whitney. Menurut Ramachandran \& Tsoko (2009:672), hipotesis statistiknya dirumuskan sebagai berikut:

$$
\begin{aligned}
\mathrm{H}_{0}: \mathrm{m}_{1}=\mathrm{m}_{2} & \text { Tidak terdapat perbedaan } \\
& \text { peningkatan kemampuan } \\
& \text { komunikasi matematik } \\
& \text { siswa MA antara yang } \\
& \text { pembelajarannya } \\
& \text { menggunakan Contextual } \\
& \text { Teaching and Leaning } \\
& \text { dengan yang menggunakan } \\
& \text { pembelajaran biasa) } \\
\mathrm{H}_{1}: \mathrm{m}_{1}>\mathrm{m}_{2} & \text { Peningkatan kemampuan } \\
& \text { komunikasi matematik } \\
& \text { siswa MA antara yang } \\
& \text { pembelajarannya } \\
& \text { menggunakan Contextual } \\
& \text { Teaching and Learning } \\
& \text { lebih baik daripada yang } \\
& \text { menggunakan } \\
& \text { pembelajaran biasa) }
\end{aligned}
$$

Keterangan:

$$
\begin{array}{cccr}
\mathrm{m}_{1} & \text { : median } & \text { skor } & \multicolumn{1}{c}{\text { N-Gain }} \\
& \text { kemampuan } & \multicolumn{2}{c}{\text { komunikasi }} \\
\text { matematik } & \multicolumn{2}{c}{\text { kelas }} & \text { yang } \\
& \text { pembelajarannya } & \text { menggunakan } \\
\mathrm{m}_{2} & \text { Contextual } & \text { Teaching } & \text { and Leaning } \\
& \text { : median } & \text { skor } & \mathrm{N}-\text { Gain } \\
& \text { kemampuan } & & \text { komunikasi } \\
& \text { matematik } & \text { kelas } & \text { yang }
\end{array}
$$


pembelajarannya menggunakan pembelajaran biasa

Nilai Sig. harus dibagi dua karena dengan menggunakan software IBM SPSS Statistics 20 dimana nilai Sig. dilakukan untuk melihat uji dua pihak. Sedangkan yang digunakan pada pengujian ini untuk memihak kepada salah satu pihak sebagaimana hipotesis penelitian. Menurut Uyanto (2009:145) bahwa tampilan signifikan dari SPSS adalah untuk uji dua pihak (2-tailed), karena kita akan melakukan uji hipotesis satu pihak (1tailed) maka nilai Sig. (2-tailed) harus dibagi dua. Kriteria pengujiannya, yaitu:

Jika Sig. $(1$-tailed $)=\frac{1}{2} \times$ Sig. $(2$-tailed $)>$ 0,05 maka $\mathrm{H}_{0}$ diterima

Jika Sig. $(1$-tailed $)=\frac{1}{2} \times$ Sig. $(2$-tailed $) \leq$ 0,05 maka $\mathrm{H}_{0}$ ditolak

Berikut adalah tabel hasil pengujian dengan menggunakan software IBM SPSS Statistics 20,

\section{Tabel 10}

Uji Mann-Whitney Data N-Gain Kemampuan Komunikasi Matematik

\begin{tabular}{|l|r|r|}
\hline & \multicolumn{1}{|c|}{$\begin{array}{c}\text { Skor N-Gain } \\
\text { Kemampuan } \\
\text { Komunikasi } \\
\text { Matematik }\end{array}$} & Interpretasi \\
\hline Mann-Whitney U & 83.000 & \multirow{2}{*}{$\mathrm{H}_{0}$ ditolak } \\
\hline Wilcoxon W & 293.000 & \\
\hline Z & -3.166 & \\
\cline { 1 - 2 } $\begin{array}{l}\text { Asymp. Sig. (2- } \\
\text { tailed) }\end{array}$ & .002 & \\
\hline $\begin{array}{l}\text { Exact Sig. [2*(1- } \\
\text { tailed Sig.)] }\end{array}$ & $.001^{\mathrm{b}}$ & \\
\hline
\end{tabular}

Berdasarkan data pada Tabel 10 terlihat bahwa statistika uji Z = -3,166 dengan Sig. (2-tailed) adalah 0,002 sehingga Sig. (1tailed) menjadi $\frac{0,002}{2}=0,001$, nilai tersebut memenuhi kriteria Sig. (1-tailed) $\leq 0,05$ maka $\mathrm{H}_{0}$ ditolak yang artinya peningkatan kemampuan komunikasi matematik siswa
MA yang pembelajarannya menggunakan Contextual Teaching and Learning lebih baik daripada yang menggunakan pembelajaran biasa.

\section{SIMPULAN}

Berdasarkan hasil analisis dan pembahasan yang telah dipaparkan, maka diperoleh kesimpulan dengan berikut:

1. Pencapaian kemampuan komunikasi matematik siswa MA yang pembelajarannya menggunakan Contextual Teaching and Learning lebih baik daripada yang menggunakan pembelajaran biasa.

2. Peningkatan kemampuan komunikasi matematik siswa MA yang pembelajarannya menggunakan Contextual Teaching and Learning lebih baik daripada yang menggunakan pembelajaran biasa.

\section{DAFTAR PUSTAKA}

Abdurahman, D. (2014). Meningkatkan Kemampuan Penalaran dan Komunikasi serta Disposisi Matematika Siswa SMP melalui Pembelajaran Inkuiri Terbimbing. Tesis UPI. Bandung: Tidak diterbitkan.

Bernard, M. (2015). Meningkatkan Kemampuan Komunikasi dan Penalaran Serta Disposisi Matematik Siswa SMK dengan Pendekatan Kontekstual melalui Game Adobe Flash CS 4. Dalam Infinity Jurnal Pendidikan Matematika STKIP Siliwangi Bandung. Volume 4, No. 2 halaman 197-222.

Darmajari, Heriawan dan Senjaya. (2012). Metodologi Pembelajaran Kajian Teoritis Praktis. Banten: $\mathrm{LP}_{3} \mathrm{G}$.

Fajriani, M. F. (2016). Pendekatan ModelEliciting Activities untuk Mengembangkan Kemampuan Komunikasi dan Berpikir Kreatif Serta 
Habits Of Mind Matematik Siswa SMP. Tesis STKIP SIliwangi Bandung. Cimahi: Tidak diterbitkan.

Firmansyah. (2013). Pentingnya Matematika dalam Kurikulum 2013. [Online]. Tersedia:

http://www.sman1subang.sch.id/html/in $\underline{\text { dex.php?id=artikel\&kode }=32} \quad\left[\begin{array}{ll}10 & \text { Mei }\end{array}\right.$ 2017]

Hartono, R. (2014). Ragam Model Mengajar yang Mudah Diterima Murid. Bandung: DIVA Press.

Hidayat, E. (2009). Peningkatan Kemampuan Komunikasi Matematik dan Kemandirian Belajar Siswa SMP dengan menggunakan Pendekatan Matematik Realistik. Tesis SPs UPI. Bandung: Tidak Diterbitkan.

Hulukati, E. (2005). Pengembangan Kemampuan Komunikasi dan Koneksi Matematika Siswa SMP melalui Pendekatan Pembelajaran Generatif. Disertasi SPs UPI. Bandung: Tidak diterbitkan.

Ramachandran, K. M. dan Tsoko. C. P. (2009). Mathematical Statistics with Applications. London, UK: Elsevier Academic Press.

Reba'i, M. (2014). Pembelajaran Matematik Saintifik.[Online]. Tersedia: http://marionrebai.blogspot.co.id/2014/04 /pembelajaran-matematika-saintifik. $\underline{\mathrm{html}}$ [10 Mei 2017]

Rohaeti. E. E. (2003). Pembelajaran Matematika dengan Menggunakan Metode Improve untuk Meningkatkan Pemahaman dan Kemampuan Komunikasi Matematik Siswa Sekolah Lanjutan Tingkat Pertama. Tesis UPI: Bandung. Tidak diterbitkan.

Rohmah, M. S. (2013). Pendekatan Brainstroming Teknik Round Robin,untuk Meningkatkan Kemampuan
Penalaran, Komunikasi Matematis dan Self-awarenes Siswa SMP. Tesis UPI. Bandung: Tidak diterbitkan.

Ruseffendi, E. T. (2005). Dasar-dasar Penelitian Pendidikan dan Bidang NonEksakta Lainnya. Bandung: Tidak diterbitkan.

Ruseffendi, E. T. (2006). Pengantar Kepada Membantu Guru Mengembangkan Kompetensinya dalam Pengajaran Matematika untuk Meningkatkan CBSA. Bandung: Tarsito.

Ruseffendi, E. T. (2010). Dasar-dasar Penelitian Pendidikan dan Bidang NonEksakta Lainnya. Bandung: Tarsito.

Sumarmo, U. (2012). Bahan Belajar Mata Kuliah Proses Berpikir Matematik Program S2 Pendidikan Matematika STKIP Siliwangi Bandung 2012. Bandung: Tidak diterbitkan.

Susilawati, W. (2014). Belajar dan Pembelajaran Matematika. Bandung: Insan Mandiri.

Uyanto, S. (2009). Pedoman Analisis Data dengan SPSS. Yogyakarta: Graha Ilmu.

Zanthy, L. S. (2011). Peningkatan Komunikasi Matematis Siswa MTs dengan Menggunakan Virtual Manipulative dalam Contextual Teaching and Learning. Tesis UPI. Bandung: Tidak diterbitkan. 